Clim. Past Discuss., https://doi.org/10.5194/cp-2019-30

Manuscript under review for journal Clim. Past

Discussion started: 20 March 2019

(c) Author(s) 2019. CC BY 4.0 License.

\title{
LACK OF MARINE ENTRY INTO MARMARA AND BLACK SEA-LAKES INDICATE LOW RELATIVE SEA LEVEL DURING MIS 3 IN THE NORTHEASTERN MEDITERRANEAN
}

\author{
Anastasia G. Yanchilina ${ }^{1}$, Celine Grall ${ }^{2}$, William B.F. Ryan² ${ }^{2}$ Jerry F. McManus ${ }^{2}$, Candace \\ O. Major $^{3}$ \\ ${ }^{1}$ Department of Earth and Planetary Sciences, Weizmann Institute of Science, Rehovot, Israel \\ 7610001. \\ ${ }^{2}$ Lamont-Doherty Earth Observatory, Columbia University, 61 Route 9W, Palisades, New \\ York 10964. \\ ${ }^{3}$ National Science Foundation, 2415 Eisenhower Ave., Alexandria, Virginia 22314 \\ Correspondence: Anastasia Yanchilina (anastasia.yanchilina@weizmann.ac.il)
}

\begin{abstract}
The Marine Isotope Stage 3 (MIS 3) is considered a period of persistent and rapid climate and sea level variabilities during which eustatic sea level is observed to have varied by tens of meters. Constraints on local sea level during this time are critical for further estimates of these variabilities. We here present constraints on relative sea level in the Marmara and Black Sea regions in the northeastern Mediterranean, inferred from reconstructions of the history of the connections and disconnections (partial or total) of these seas together with the global ocean. We use a set of independent data from seismic imaging and core-analyses to infer that the Marmara and Black Seas remained connected persistent freshwater lakes that outflowed to the global ocean during the majority of MIS 3. Marine water intrusion during the early MIS-3 stage may have occurred into the Marmara Sea-Lake but not the Black Sea-Lake. This suggests that the relative sea level was near the paleo-elevation of the Bosporus sill and possibly slightly above the Dardanelles paleo-elevation, $\sim 80 \mathrm{mbsl}$. The Eustatic sea level may have been even lower, considering the isostatic effects of the Eurasian ice sheet would have locally uplifted the topography of the northeastern Mediterrranean.
\end{abstract}

\section{Introduction}

Marine isotope stage 3 (MIS 3) is identified as the period between 60 and 25 kyr B.P., when regional and global climate fluctuated over a broad range of temperatures on millennial time scales (Dansgaard et al. 1993, Members 2006). One particularly noteworthy and intriguing aspect of MIS 3 is its characteristic sequence of abrupt climate fluctuations including the iconic Dansgaard-Oeschger (D-O) bi-polar oscillations and Heinrich event iceberg discharges with corresponding fluctuations in global sea level on the order of $\sim 20-40 \mathrm{~m}$ (Siddall et al. 2008). The eustatic sea level (ESL) during this period remains uncertain, with sea level elevations that range as low as 87 meters below today's sea level (mbsl) to as high as $25 \mathrm{mbsl}$ (Siddall et al. 2008). The lack of existence of a rigorous constraint on ESL has implications 
Clim. Past Discuss., https://doi.org/10.5194/cp-2019-30

Manuscript under review for journal Clim. Past

Discussion started: 20 March 2019

(c) Author(s) 2019. CC BY 4.0 License.

41 for understanding factors that control ice-sheet growth and collapse. Ice volume variations are

42 additionally an important input into glacial isostatic adjustment (GIA) models (Pico et al.

43 2016), that are in turn used to understand changes in the distribution of ice volume on the planet

44 and its effect on local sea level. It should be noted that ESL is different from Relative Sea Level

45 (RSL) as the RSL represents the elevation of the sea relative to the moving solid earth. The

46 earth is moving notably because of isostatic adjustment of the earth's surface to the changes in

47 the distribution of ice and water and the corresponding changes of the gravitational potential

48 of the earth-ocean system (Lambeck et al. 2002b). Also, the RSL can be obtained from

49 geological archives and ESL may be derived from these archives when the earth solid surface

50 motions are properly considered.

51 Several methodologies have been employed to deduce the height of past ESL: 1) ice

52 volume changes using oxygen isotope measurements of planktonic and benthic foraminifera

53 (Bintanja et al. 2005, Shakun et al. 2015) (Fig. 1a and b), 2) elevated coral terraces (Cutler et

54 al. 2003) (Fig. 1c), and 4) changes between brackish and fresh conditions in marginal basins

55 (Van Daele et al. 2011, Pico et al. 2016, Pico et al. 2017). Reconstructing ESL from the benthic

56 foraminiferal LR04 $\delta^{18} \mathrm{O}$ record using an inverse ice-sheet climate model gives sea level

57 estimates below 80 mbsl (Fig. 1a) (Bintanja et al. 2005). Isolating the ice volume from a

58 compilation of planktonic foraminiferal $\delta^{18} \mathrm{O}$ records gives a global sea level that decreases

59 from $\sim 60 \mathrm{mbsl}$ to $80 \mathrm{mbsl}$ over the course of MIS 3 (Fig. 1b) (Shakun et al. 2015). U/Th dated

60 coral terraces used as a relative sea level proxy (Lambeck et al. 2002b), suggest after

61 considering a GIA correction, that the ESL was below 60 mbsl (Fig. 1c) (Yokoyama et al.

62 2001, Peltier et al. 2006). More recent studies suggest shallower estimates of ESL during MIS

63 3. Sediment cores taken from the Yellow River Delta that similarly record fluctuations

64 between fresh and marine environments have been used to assert that ESL reached a peak of

6538 mbsl during an interval between 50 and $37 \mathrm{kyr}$ (Pico et al. 2016). Similarly, records from

66 the Albermarle Embayment on the U.S. Mid-Atlantic coast show a ESL peak level of 40 mbsl

67 during MIS 3 (Pico et al. 2017). Geological archives provide RSL indices. RSL indices are

68 critical to constrain the local ESL and Global Mean Sea Level models.

69 In this paper, we provide highstand thresholds on RSL in the Black Sea and Marmara

70 Sea system to infer information about ESL during MIS 3 using a GIA model and provide

71 valuable geological constraints on regional RSL reconstructions. In the modern configuration,

72 Black Sea and Marmara Sea are connected to the global ocean via shallow Bosporus and

73 Dardanelles Straits to form an interconnected lake-ocean system (Çagatay 2003). During 
Clim. Past Discuss., https://doi.org/10.5194/cp-2019-30

Manuscript under review for journal Clim. Past

Discussion started: 20 March 2019

(c) Author(s) 2019. CC BY 4.0 License.

74 glacial periods, this configuration can change if the RSL falls below the straits, cutting off

75 marine water entry. Here we use observations from geochemical records and seismic images

76 to reconstruct water connection and disconnection histories between the Black Sea, Marmara

77 Sea, and the global ocean. We show that the two lakes were freshwater, connected, and

78 outflowing excess freshwater to the East Mediterranean for a large fraction of MIS 3, with the

79 exception of a possible transient marine entry from $55 \mathrm{kyr}$ B.P. to $44 \mathrm{kyr}$ B.P. We then provide

80 different independent estimates on paleo-lake elevations and sill elevations to provide a

81 database of RSL estimates and discuss the possible implication on the local ESL. In this paper,

82 we will refer to the Sea of Marmara and the Black Sea as Marmara Sea-Lake and Black Sea-

83 Lake, taking into account their prior freshwater state.

\section{Inferred paleo-salinity in the Marmara Sea-Lake and Black Sea-Lake during MIS 3} from previous studies

Previous studies have documented the $\mathrm{CaCO}_{3}$ accumulation in the Marmara Sea (Çağatay et al. 2015) and $\mathrm{Ca}$ (\%) accumulation in the Black Sea (Nowaczyk et al. 2012), porewater $\mathrm{Cl}^{-}$in the Marmara Sea (Aloisi et al. 2015) and Black Sea (Soulet et al. 2010), and last, $\delta^{18} \mathrm{O}$ composition of the Black Sea mollusk record (Major et al. 2006, Yanchilina et al. 2017) and Marmara Sea mollusk record (Vidal et al. 2010).

$\mathrm{CaCO}_{3}$, although a proxy that cannot be used as a direct measurement of paleosalinity, it can be used to interpret the connectivity between water bodies. $\mathrm{CaCO}_{3}$ in lakes reflects the integration between sedimentation rate and $\mathrm{CO}_{3}$-assimilation and $\mathrm{pH}$-changes induced by phytoplankton blooms. Higher $\mathrm{CaCO}_{3}$ becomes deposited during warmer periods when there are more phytoplankton blooms relative to colder periods. Specific to our case, the Sea of Marmara is small in volume relative to the volume of the Black Sea and also, does not have a significant amount of independent river inflow. Hence, the temporal synchronicity of $\mathrm{CaCO}_{3}$ variability between both basins is inferred to reflect connectivity of the two lakes and to indicate outflows of the Black Sea-Lake into the Marmara Sea-Lake. Although fresh, both lakes are likely to have been somewhat alkaline in order to account for episodes of organic and inorganic carbonate accumulation at times of rapid warming during each of the Dansgaard/Oeschger events (Çağatay et al. 2015). 
Clim. Past Discuss., https://doi.org/10.5194/cp-2019-30

Manuscript under review for journal Clim. Past

Discussion started: 20 March 2019

(c) Author(s) 2019. CC BY 4.0 License.

Application of an advection/diffusion model allows to qualitatively deconstruct paleosalinity. The modern values for the Sea of Marmara and the Black Sea are $620 \mathrm{mmol} / \mathrm{L}$ and $350 \mathrm{mmol} / \mathrm{L}$ with the former corresponding to a salinity value of $\sim 39$ ppt (Soulet et al. 2010, Aloisi et al. 2015). Freshwater bodies typically have low porewater $\mathrm{Cl}^{-}$composition (i.e., $<\sim 50 \mathrm{mmol} / \mathrm{L}$ ). A decrease of porewater $\mathrm{Cl}^{-}$towards these values would indicate that these bodies of water were fresher in the past. After taking into account advection and diffusion, porewater $\mathrm{Cl}^{-}$values indicate both of the seas were fresh during MIS 3 and possibly also the late part of MIS 4 (Soulet et al. 2010, Aloisi et al. 2015).

The $\delta^{18} \mathrm{O}$ composition of the mollusks from the Black Sea is measured to be $-6 \pm 1 \%$ (Major et al. 2006, Yanchilina et al. 2017) and the $\delta^{18} \mathrm{O}$ composition of the Sofular Cave stalagmites is measured to be $-12 \pm 1 \%$ during the MIS 3 (Fleitmann et al. 2009, Badertscher et al. 2011). The resolution of the U/Th ages for the Sofular Cave stalagmites for MIS 3 is, on average, 24 years (Fleitmann et al. 2009). $\delta^{18} \mathrm{O}$ of $-6 \%$ measured in the Black Sea mollusks is the value that reflects the $\delta^{18} \mathrm{O}$ composition of the mollusks during the last glacial period, MIS 2, when the Black Sea was shown to be a freshwater lake. The $\delta^{18} \mathrm{O}$ of $-12 \%$ of the Sofular Cave stalagmites is shown to reflect the evaporation of Black Sea water with a constant offset of $-6 \%$, the difference argued to account for fractionation of water as a consequence of distillation effects (Fleitmann et al. 2009, Badertscher et al. 2011). Given the observation that the $\delta^{18} \mathrm{O}$ of the Sofular Cave stalagmites remains at $-12 \%$ all throughout MIS 3 indicates the Black Sea was also fresh for the entirety of this period. Furthermore, freshwater mollusk Dreissena rostriformis, and dinoflagellates $S$. cruciformis and $P$. psilata persistently dominate the MIS 3 faunal composition in the Black Sea-Lake (Rochon et al. 2002, Yanchilina et al. 2017).

We will further evaluate these observations and prior interpretations from comparison of variations in ${ }^{87} \mathrm{Sr} /{ }^{86} \mathrm{Sr}$ measured in ostracod and mollusk shells from both Black Sea and Marmara Sea basins. Contrary to the $\delta^{18} \mathrm{O}$ composition of water, a variable that incorporates changes in the hydrological cycle of lake systems, ${ }^{87} \mathrm{Sr} /{ }^{86} \mathrm{Sr}$ of water responds exclusively to changes in source of water and can differentiate between changes in input from the different sources. ${ }^{87} \mathrm{Sr} /{ }^{86} \mathrm{Sr}$ is especially relevant to measure when making an attempt to identify inputs of saline water into lake systems. Because of the low concentration of freshwater $\mathrm{Sr}$ from rivers, even a small input of marine water, rich in $\mathrm{Sr}$, will make an observable change in the ${ }^{87} \mathrm{Sr} /{ }^{86} \mathrm{Sr}$ composition of freshwater bodies of water. ${ }^{87} \mathrm{Sr} /{ }^{86} \mathrm{Sr}$ is a very sensitive proxy used previously to reconstruct the deglacial entry of marine water into the Black Sea-Lake during the Holocene 
Clim. Past Discuss., https://doi.org/10.5194/cp-2019-30

Manuscript under review for journal Clim. Past

Discussion started: 20 March 2019

(c) Author(s) 2019. CC BY 4.0 License.

140 (Major et al. 2006, Yanchilina et al. 2017). The modern ${ }^{87} \mathrm{Sr} /{ }^{86} \mathrm{Sr}$ composition of river water

141 inflowing into the Black Sea is $\sim 0.7088$ (Palmer et al. 1989) whereas the ${ }^{87} \mathrm{Sr} /{ }^{86} \mathrm{Sr}$ composition

142 of the ocean water is 0.709155 (Henderson et al. 1994).

\section{Materials and Methods}

3.1 Geochemistry

We measured ${ }^{87} / 86 \mathrm{Sr}$ of ostracodes and mollusks from the Marmara Sea sediments and compared these measurements with the published values from the Black Sea (Major et al. 2006, Yanchilina et al. 2017). The sediments were taken from cores ITU-C1 at $73 \mathrm{mbsl}$, MD01-2426 at $250 \mathrm{mbsl}$, ITU-C10 at $364 \mathrm{mbsl}$, and MD01-2430 at $580 \mathrm{mbsl}$ (Fig. 2). MD01-2426 and MD01-2430 were retrieved in 2001 during the MD123/MARMACORE cruise (R/V Marion Dufresne). MD01-2426 was collected from north of the Imrali ridge and MD01-2430 was collected on the Western High between the Central and the Tekirdag deep basins (Grall et al. 2013). ITU-C1 and -C10 were retrieved in 2002 with R/V MTA Sismik 1 in and around the Sarkoy Canyon in the Western Marmara Sea. The ${ }^{87} \mathrm{Sr} /{ }^{86} \mathrm{Sr}$ records for the Sea of Marmara were measured at Lamont-Doherty Earth Observatory, Columbia University. Sr was initially leached to retrieve the Sr fraction (Bailey et al. 2000) which was then loaded upon tungsten filaments with $\mathrm{TaCl} 5$ (Birck 1986). ${ }^{87} \mathrm{Sr} /{ }^{86} \mathrm{Sr}$ ratios were measured using a dynamic multicollector on a VG thermal ionization mass spectrometer and normalized to ${ }^{86} \mathrm{Sr} /{ }^{88} \mathrm{Sr}=0.1194$ to correct for mass fractionation. Beam size was tuned to be close to $5.0 \times 10-11$ for ${ }^{88} \mathrm{Sr}$. ${ }^{87} \mathrm{Sr} /{ }^{86} \mathrm{Sr}$ measurements were monitored to account for instrumental drift through periodically running NBS987 which gave ${ }^{87} \mathrm{Sr} /{ }^{86} \mathrm{Sr}=0.710288( \pm 0.000015)$ with a $2 \sigma$ external reproducibility, $\mathrm{n}=16$. The original age model was constructed from ${ }^{14} \mathrm{C}$ measurements and calibrated to calendar age with a zero reservoir correction. Although the original ${ }^{14} \mathrm{C}$ measurements have been misplaced, we compose our own age model from ${ }^{14} \mathrm{C}$ measurements made from pieces of mollusks from MD01-2430 (Vidal et al. 2010) which we correct for reservoir after tuning its $\delta^{18} \mathrm{O}$ record to that of the Black Sea and Sofular Cave $\delta^{18} \mathrm{O}$ records.

167 This procedure follows from the observation that the $\delta^{18} \mathrm{O}$ of the Sofular Cave $\delta^{18} \mathrm{O}$ record 168 reflects the $\delta^{18} \mathrm{O}$ composition of Black Sea surface water (Fleitmann et al. 2009, Badertscher 169 et al. 2011) which, before the connection of the Marmara Sea-Lake with the Mediterranean Sea

170 reflected predominantly the $\delta^{18} \mathrm{O}$ composition of the Black Sea-Lake that flowed through the 171 Bosporus Strait into the Sea of Marmara. The results are presented in Supplementary Materials 1721 and illustrated in Fig. 3 a. 
Clim. Past Discuss., https://doi.org/10.5194/cp-2019-30

Manuscript under review for journal Clim. Past

Discussion started: 20 March 2019

(c) Author(s) 2019. CC BY 4.0 License.

3.2 Chirp profiles

175

We present a chirp record of a perched pond/lake, lake Gemlik (Figs. 2, 4), from Sea of Marmara in order to diagnose whether any marine entry occurred during MIS 3. The chirp profile was acquired during Sensing the Ocean with Marine Radars (SoMAR) cruise on the R/V K. Piri Reis in 2013 with SyQwest-Bathy 2010 chirp profiler and operating frequency of 3.5 KHz. This perched lake is observed on the southern shelf of the Marmara Sea (Fig. 2). It is separated from the deeper sections of the Marmara Sea by the Imrali ridge with a depth of 50 mbsl. Lake Bandirma is also indicated (Fig. 2) observed to lie to the east of Lake Gimlik but a chirp profile for was not acquired.

\section{Results}

4.1 Paleosalinity and paleo-connectivity of Marmara and Black Sea during MIS 3

${ }^{87} \mathrm{Sr} /{ }^{86} \mathrm{Sr}$ measurements of the Marmara Sea mollusks at the beginning of MIS 2 vary around 0.7088 (Figure 3a), a value that is similar to the ${ }^{87} \mathrm{Sr} /{ }^{86} \mathrm{Sr}$ composition of the Black Sea during this period and also to the average ${ }^{87} \mathrm{Sr} /{ }^{86} \mathrm{Sr}$ composition of river water flowing into the Black Sea of 0.7088 (Palmer and Edmond 1989). ${ }^{87} \mathrm{Sr} /{ }^{86} \mathrm{Sr}$ composition of Black Sea mollusks also has a strictly lacustrine composition of $0.70880 \pm 5 \mathrm{E}-5$ at the end of MIS 3 (Fig. 3a). The ${ }^{87} \mathrm{Sr} /{ }^{86} \mathrm{Sr}$ of freshwater mollusks from the Marmara Sea-Lake follows closely that of the Black Sea record through the deglaciation and is also lacustrine at the beginning of MIS 2. For the two lakes to share the identical ${ }^{87} \mathrm{Sr} /{ }^{86} \mathrm{Sr}$ composition similar to the composition of river inflow into the Black Sea, the Black Sea must have been fresh and outflowing to the Sea of Marmara. The Sea of Marmara must have subsequently outflowed to the Mediterranean Sea, as it's a much smaller volume relative to the Black Sea. We present supporting data to contest that the two lakes were freshwater, connected, and outflowing excess freshwater to the East Mediterranean for a large fraction of MIS 3.

Comparing together sediment $\mathrm{Ca}$ and $\mathrm{CaCO}_{3}$ (Nowaczyk et al. 2012, Çağatay et al. 2015) (Fig. 3b) with the porewater $\mathrm{Cl}^{-}$(Soulet et al. 2010, Aloisi et al. 2015) (Fig. 3c) from the Black and Marmara Seas and Sofular Cave $\delta^{18} \mathrm{O}$ of the stalagmites (Fleitmann et al. 2009, Badertscher et al. 2011) (Fig. 3d) support this interpretation. The $\mathrm{Ca}$ and $\mathrm{CaCO}_{3}$ of the Black Sea-Lake and Marmara Sea-Lake are identical for all of MIS 3 with the exception of the period from 55 to 44 kyr B.P., in which either the Black Sea-Lake suspended outflow to the Marmara Sea-Lake and/or there was a potential marine entry into the Marmara Sea-Lake but not the 
Clim. Past Discuss., https://doi.org/10.5194/cp-2019-30

Manuscript under review for journal Clim. Past

Discussion started: 20 March 2019

(c) Author(s) 2019. CC BY 4.0 License.

Black Sea-Lake. The latter is less likely to have occurred as every marine entry recorded into both the Marmara and Black Sea-Lakes is followed by a formation of a sapropel, evidence of which here is not observed. We still consider this possibility in case the transient marine entry was minor and perhaps was just a small inflow.

Porewater $\mathrm{Cl}^{-}$in Marmara Sea-Lake sediments differs from that of the Black Sea-Lake

212

213 sediments as a result of the earlier connection of the Marmara Sea with the global ocean and higher post-connection salinity, leading to an earlier diffusion of marine water into the previously lacustrine sediments. If there had been any marine inflow into either sea during MIS 3, there would be observable remnant diffusion trends. In fact, $\mathrm{Cl}$ - decreases back through time and into MIS 4 to $100 \mathrm{mmol} / \mathrm{L}$, suggesting the Marmara Sea-Lake was also fresh during this period and the freshening had to have happened even earlier. There is only one point during which the $\mathrm{Cl}$ - is observed to increase, $50 \mathrm{kyr}$ B.P., and we discuss this in this paper, with the light of supplemental Sr analyses. Pore-water chloride, $\delta^{18} \mathrm{O}$ and ${ }^{87} \mathrm{Sr} /{ }^{86} \mathrm{Sr}$ of mollusks and ostracods do not indicate any significant rises in salinity in the Marmara and Black SeaLakes.

$\delta^{18} \mathrm{O}$ composition of the Sofular Cave stalagmites, porewater $\mathrm{Cl}$ - and sediment $\mathrm{CaCO}_{3}$ results support this interpretation. The $\delta^{18} \mathrm{O}$ of Black Sea-Lake and Marmara Sea-Lake carbonate reflects the composite of hydrological balance in the basin through integration of inputs in the form of river and rain water and outputs in the form of evaporative processes (Major et al. 2006). A lower $\delta^{18} \mathrm{O}$ value is considered to be fresh and in a positive hydrological framework whereas a higher $\delta^{18} \mathrm{O}$ value is considered to reflect either entrance of marine water and/or a drier climate, preferentially removing the lighter oxygen isotope (i.e., $\left.{ }^{16} \mathrm{O}\right)$ from the water (Deuser 1972). We use the $\delta^{18} \mathrm{O}$ composition of the dated Sofular Cave stalagmites with a temporal resolution of $\delta^{18} \mathrm{O}$ measurements of $\sim 24$ years to infer the paleosalinity further back in time, a measurement previously shown to reflect the composition of the Black Sea water vapor (Badertscher et al. 2011). The most recent entry of marine water resulted in a rapid increase in salinity to modern values in both the Black Sea-Lake (Major et al. 2006; Yanchilina et al. 2017) and in the Marmara Sea-Lake (Sperling et al. 2003). This is not observed on the $\delta^{18} \mathrm{O}$ records, suggesting both basins remain fresh.

4.2 MIS 3 Relative Sea Level Index in Marmara Sea-Lake and Black Sea-Lake.

Wave-cut cliffs and their corresponding terraces are observed everywhere in the subsurface of the outermost Marmara Sea continental shelf at elevations close to the modern 
Clim. Past Discuss., https://doi.org/10.5194/cp-2019-30

Manuscript under review for journal Clim. Past

Discussion started: 20 March 2019

(c) Author(s) 2019. CC BY 4.0 License.

240 Dardanelles bedrock sill at $\sim 65$ mbsl (Gokasan et al. 2008) (Supplementary Material 2-6, Table

241 1). At the distal edge of each terrace, one observes inclined clinoforms (Çağatay et al. 2009) indicative of subaqueous prodelta foresets that are truncated by an erosion surface (Vardar et al. 2014). Where sampled, the youngest foresets of these clinoforms are of early MIS-2 age (Yaltirak et al. 2002, Ergin et al. 2007, Çağatay et al. 2009, Karakilcik et al. 2014, Vardar et al. 2014). The mollusk assemblage, composed of exclusively freshwater species (i.e., Dreissena $r$.) in core MD04-2745 that sampled the entire succession of incline strata, indicates there was no observable entry of marine water during MIS 4, 3, and 2. Older MIS 5 deposits outcrop at elevations up to $7 \mathrm{~m}$ above today's sea level on the edge of the Dardanelles Strait (Supplementary Material 6, Table 1) (Yaltirak et al. 2002).

Table 1

Figure name Source

SU 2 Gökaşan et al. (2010)

SU 3 Karakilcik et al. (2014)

SU 4 Ergin et al. (2007)

SU 5 Smith et al. (1995)

SU 6 Gökaşan et al. (2010)

\section{Key observations}

MIS 2-3-4 foresets in the Marmara Sea-Lake, seaward of Prince

Islands, below $80 \mathrm{mbsl}$

MIS 2-3-4 foresets in the Marmara Sea-Lake, Çekmeke shelf break, lower than $90 \mathrm{mbsl}$

MIS 2-3-4 foresets, northwest margin of Marmara Sea, lower than 75 mbsl. The youngest foreset is ${ }^{14} \mathrm{C}$ dated to MIS 2 .

MIS 2-3-4 foresets, west of Imrali Island in the Marmara Sea, lower than 70 mbsl.

Paleo-elevation of the Dardanelles strait is inferred to be $85 \mathrm{mbsl}$.

In the southern shelf of the Marmara Sea, both the Gemlik and Bandirma lakes are interpreted to have been separated from the large main Marmara Sea-Lake by the Imrali ridge during MIS 2, 3, and 4 (Vardar et al. 2014) (Fig. 4). Chirp records show no evidence at all of MIS 3 and 2 sediments on the shelves except in these perched ponds. The paleo-shorelines of the Bandirma and Gemlik suspended lakes are observed at $\sim 50 \mathrm{mbsl}$ and $\sim 60 \mathrm{mbsl}$, respectively (Vardar et al. 2014). Thin transparent layers of Holocene age are observed on the Imrali Ridge, lying along an erosional unconformity $(\mathrm{C}-\mathrm{a})$ which has been interpreted as the last marine lacustrine to marine transition. A second deeper unconformity is observed below, on the intervening shelf region as well beneath the floor of the ponded lakes (Fig. 4). The age of the deeper unconformity is unconstrained, due to the lack of recovered sediment. It has been proposed that this unconformity may be $23 \mathrm{kyr}$ or $30 \mathrm{kyr}$ (Hiscott et al. 2002, Vardar et al. 2014). This observation, however, is not compatible with the stratigraphic history of the 
Clim. Past Discuss., https://doi.org/10.5194/cp-2019-30

Manuscript under review for journal Clim. Past

Discussion started: 20 March 2019

(c) Author(s) 2019. CC BY 4.0 License.

deposits. It is shown that the MIS-2 period corresponds to a large transgressive period following the MIS-3 low stand (Çağatay et al. 2009). This suggests that the basal surface of the sediment deposited during MIS-2 should be conformable with sediment below. It is likely that this erosional surface is a consequence of the brief drying event related to the beginning of the Bolling/Allerod, immediately before entry of marine water into the Marmara Sea-Lake (McHugh et al. 2008). The bumps and valleys in Unit 2 are potentially artifacts of gas derived from below. The loss of water associated with the brief desiccation is likely to have initiated this discharge. This phenomenon came to an end after the later loading of marine water. Core data would be able to strengthen this interpretation but is at the moment unavailable. Hence, no deposition during MIS 3-2 is observed in this lake and lake level had to be below the depth of the Imrali ridge during this period.

Chirp sub-bottom profiles across the outer shelf of the western Black Sea reveal a succession of superimposed lacustrine deposits (Fig. 5) belonging to basinward prograding lowstand deltas (Aksu et al. 2002, Dimitrov 2010). On top of the youngest clinoforms are sand dunes and a berm like feature indicative of a paleoshoreface (Lericolais et al. 2009, Yanchilina 2016, Yanchilina et al. 2017). Where sampled, the youngest set of prograding strata are ${ }^{14} \mathrm{C}$ dated to late MIS 3 through MIS 2 and contain lacustrine fauna (Yanchilina et al. 2017). The succession of parallel and prograding deposits indicates alternating highstands and lowstands. If one were to consider that these clinoforms were deposited in a near-shore subaqueous prodelta environment, they indicate the surface of the Black Sea-Lake was 80 to 90 mbsl during MIS 3.

\section{Discussion} fresh and the hydrological budget was positive during most of MIS 3, with the exception of a period between 44 and $55 \mathrm{kyr}$ B.P. The hydrologic budget must have remained positive in order for (1) the perched ponds not to have dried out and (2) to account for the similarity in the elevation of the surface of the Marmara and Black Sea-Lakes and their correspondence with elevations of the Dardanelles bedrock, to maintain outflow as suggested by geochemical data (i.e., identical $\mathrm{CaCO}_{3}$ during MIS 3 and 2, low $\delta^{18} \mathrm{O}$ of Sofular Cave stalagmites, and similar ${ }^{87} \mathrm{Sr} /{ }^{86} \mathrm{Sr}$ during end of MIS $3 / 2$ ).

The similarity between the present average elevation of the lake's surface and the elevation of the Dardanelles and Bosporus Sills at $\sim 65-80$ mbsl confirms that the straits acted as outflow channels (i.e., a rivers) expelling Black and Marmara Sea-Lake freshwater to the 
Clim. Past Discuss., https://doi.org/10.5194/cp-2019-30

Manuscript under review for journal Clim. Past

Discussion started: 20 March 2019

(c) Author(s) 2019. CC BY 4.0 License.

external ocean during MIS 3 and MIS 2. This also suggests that the Dardanelles bedrock sill was at or near (by a few meters) the relative sea level. It remains possible that RSL is below by a few meters the Dardanelle paleo-sill, if freshwater flux would have been able to sustain a certain pressure to deny any marine inflow (Dalziel 1991; Lane-Serff et al. 1997; Lambeck et al. 2007). The observation of a lower lake surface that indicates that the Bosporus sill also must have been deeper than today, sitting at its bedrock at $80 \mathrm{mbsl}$. If the outlet sill was shallower, then the elevation of the foresets would likely have been higher. Substantial river entrenchment may have deepened its modern bedrock depth. For example, MIS 6, 8, 10, and 12 lowstand clinoforms in the region of Prince Islands (Supplementary Materials 2) are all at elevations as low or lower than the MIS 2 and 3 clinoforms. Thus the lake's ancient shorelines must have always had to have fallen to an elevation near to the modern bedrock elevation during each lacustrine period.

This set of independent geological archives provide RSL index with present elevation ranging between 70 and 90 mbsl. The present elevations of indexes are likely different than their paleo-elevations during MIS 3. The present elevations of indexes are likely different than their paleo-elevations during MIS 3. 10-20 m of regional subsidence has likely occurred since MIS 3, as the results of GIA associated with the overall ice-water budget in between the glacial MIS 3 time and today. This may place the RSL during MIS 3 at a maximum value of $80 \mathrm{~m}$. During MIS 3, RSL was shallower than the ESL here, in response to the GIA associated with the transition from MIS 5 interglacial stage into MIS 3. This suggests that the ESL in the region was likely below 70 mbsl during the overall MIS 3 glacial stage. This threshold on ESL is in agreement with the results from U/Th dated coral terraces corrected for GIA (Yokoyama et al. 2001) that leads to coral-based global sea level reconstructions about $\sim 58-111 \mathrm{mbsl}$ ( $\sim 5$ to -110 mbsl if error is included) (Fig. 1e) (Yokoyama et al. 2001). Four of these coral-based ESL reconstructions during MIS 3 give a range of 58 to $70 \mathrm{mbsl}$ and eight in the range of 70 to 80 mbsl. Our results on ESL supports the lower estimates obtained from scaling changes from the LR04 stack of benthic $\delta^{18} \mathrm{O}$ records (Bintanja et al. 2005), but does not entirely agree with changes in ESL from scaling changes from detrended planktonic $\delta^{18} \mathrm{O}$ records corrected for changes in temperature (Shakun et al. 2015). Our results differ from the ESL estimates from the U.S. Mid-Atlantic coast and the Yellow Sea deposits show the ocean surface was shallower than indicated by our observations during MIS 3. While these estimates serve as

341 valuable surface of sea level information, they are currently limited by a lack of clear evidence

342 of submersion by marine water and a reliance on dates from dune and channel sand. For the 
Clim. Past Discuss., https://doi.org/10.5194/cp-2019-30

Manuscript under review for journal Clim. Past

Discussion started: 20 March 2019

(c) Author(s) 2019. CC BY 4.0 License.

343 Yellow Sea, since radiocarbon dates on shells from these sediments are at the limit of

344 reliability, dating of the sand has been accomplished by OSL methods (Liu et al. 2010). The reflection profiles show that the sampled sand is from a channel fill within a dendritic drainage system, more likely of fluvial origin rather than sand from a marine transgression. Likewise, the suggested ESL peak of 40 mbsl during MIS 3 (Pico et al. 2017) in the Albermarle Embayment on the U.S. Mid-Atlantic coast is based on OSL-dated sands sampled from eolian dunes with interbedded paleo-sol and resting on peat (Mallison et al. 2008). The diagnostic evidence of a marine transgression is from mollusk shells under the peat and attributed to MIS 5. Close inspection of analyses from both the Yellow Sea and U.S. Mid-Atlantic coast suggests assigning a marine transgression to these two areas needs further scrutiny and cannot be concretely assigned to a eustatic sea level highstand during MIS 3.

\section{Conclusions}

Paleosalinity interpretations from measurements of $\mathrm{Ca}$ and $\mathrm{CaCO}_{3}$, porewater $\mathrm{Cl}^{-}, \delta^{18} \mathrm{O}$ and ${ }^{87} \mathrm{Sr} /{ }^{86} \mathrm{Sr}$ composition of mollusks from Black Sea and Marmara Seas, $\delta^{18} \mathrm{O}$ composition of the Sofular Cave stalagmite records indicate the two seas were freshwater lakes, connected, and outflowing to the Mediterranean Sea for the majority of MIS 3, with the possible exception of a period encompassing 55 to 44 kyr B.P. Lack of marine entry through most of this period is supported by evidence of ponded/perched lakes in the Marmara Sea that lack any observable marine deposits. In the future, it is critical to obtain $\delta^{18} \mathrm{O}$ and ${ }^{87} \mathrm{Sr} /{ }^{86} \mathrm{Sr}$ measurements in carbonates for the Black and Marmara Sea-Lakes during this period to make more robust conclusions about the paleo-connectivity and outflow of these basins. Low $\delta^{18} \mathrm{O}$ of $\sim-6 \%$ and ${ }^{87} \mathrm{Sr} /{ }^{86} \mathrm{Sr}$ of $\sim 0.7088$ would show that the water in these lakes was fresh and fed by Black Sea river water.

Clinoforms, wave cut cliffs and corresponding terraces indicate that the lake level of the two sea-lakes was at 80 to $90 \mathrm{mbsl}$ during this period, suggesting a positive water budget and outflow. Both of the sills, the Bosporus that connects the Black Sea with the Marmara Sea and the Dardanelles that connects the Marmara Sea with the Mediterranean Sea were at the level of the paleoshoreline. If the RSL on the Mediterranean side of the Dardanelles sill was higher than the level of the sill, there should be indication of marine entry. As there is not, we conclude, with taking wave base into consideration, the RSL must have been at or below the level of the sills, maximum at $65-70 \mathrm{mbsl}$, for the majority of the period with the exception of 55 to 44 kyr B.P. ESL should have been even lower during this period, as $10-20 \mathrm{~m}$ of local 
subsidence would have occurred as a consequence of the changes in the distribution of ice

sheets in Eurasia from MIS 3 to present.

\section{References}

Aksu, A. E., R. N. Hiscott, M. A. Kaminski, P. J. Mudie, H. Gillespie, T. Abrajano and D. Yaşar: Last glacial-Holocene paleoceanography of the Black Sea and Marmara Sea: stable isotopic, foraminiferal and coccolith evidence, Marine Geology, 190, 119-49, 10.1016/S0025-3227(02)00345-6, 2002.

Aksu, A. E., C. Yaltirak and R. N. Hiscott: Quaternary paleoclimatic -paleoceanographic and tectonic evolution of the Marmara Sea and environs, Marine Geology, 190, 9-18, 2002.

Aloisi, G., G. Soulet, P. Henry, K. Wallmann, R. Sauvestre, C. Vallet-Coulomb, C. Lécuyer and E. Bard: Freshening of the Marmara Sea prior to its post-glacial reconnection to the Mediterranean Sea, Earth and Planetary Science Letters, 413, 176-85, 10.1016/j.epsl.2014.12.052, 2015.

Badertscher, S., D. Fleitmann, H. Cheng, R. L. Edwards, O. M. Göktürk, A. Zumbühl, M. Leuenberger and O. Tüysüz: Pleistocene water intrusions from the Mediterranean and Caspian seas into the Black Sea, Nature Geoscience, 4, 236-39, 10.1038/NGEO1106, 2011.

Bailey, T. R., J. M. McArthur, H. Prince and M. F. Thirwall: Dissolution methods for strontium isotope stratigraphy: Whole rock analysis, Chemical Geology, 167, 313-19, 2000.

Bintanja, R., R. S. W. van De Wal and O. Johannes: Modelled atmospheric temperatures and global sea levels over the past million years, Nature, 437, 125-28, 2005.

Birck, J.-L.: Precision K-Rb-Sr isotopic analysis; applications to Rb-Sr chronology, Chemical Geology, 56, 73-83, 1986.

Çagatay, M. N., Water Exchange Between Mediterranean and Black Seas During Late Glacial-Holocene: Evidence from Marmara and Black Seas, Annual Meeting Geological Society of America, Seattle. WA, Geological Society of America, 2003.

Çağatay, M. N., K. Eriş, W. B. F. Ryan, Ü. Sancar, A. Polonia, S. Akçer, D. Biltekin, L. Gasperini, N. Görür, G. Lericolais and E. Bard: Late Pleistocene-Holocene evolution of the northern shelf of the Sea of Marmara, Marine Geology, 265, 87-100, 10.1016/j.margeo.2009.06.011, 2009.

Çağatay, M. N., S. Wulf, Ü. Sancar, A. Özmaral, L. Vidal, P. Henry, O. Appelt and L. Gasperini: The tephra record from the Sea of Marmara for the last ca. $70 \mathrm{ka}$ and its paleoceanographic implications, Marine Geology, 361, 96-100, 10.1016/j.margeo.2015.01.005, 2015.

Cutler, K. B., R. L. Edwards, F. W. Taylor, H. Cheng, J. Adkins, C. D. Gallup, P. M. Cutler, G. S. Burr and A. L. Bloom: Rapid sea-level fall and deep-ocean temperature change since the last interglacial period, Earth and Planetary Science Letters, 206, 253-71, 10.1016/S0012-821X(02)01107-X, 2003.

Dansgaard, W., S. J. Johnsen, H. B. Clausen, D. Dahl-Jensen, N. Gundenstrup, C. U. Hammer, C. S. Hvidberg, J. P. Steffensen, A. E. Sveinbjörnsdóttir, J. Jouzel and G. Bond: Evidence for general instability of past climate from a 250-kyr ice core, Nature, 364, 218-20, 1993.

Deuser, W. G.: Late-Pleistocene and Holocene history of the Black Sea as indicated by stable isotope studies, Jour. Geophys. Res., 77, 1071-77, 1972. 
Dimitrov, D., Geology and non-traditional resources of the Black Sea, Germany, Lambert Academik Publishing AG, 2010.

Ergin, M., E. Uluadam, K. Sarikavak, Ş. Keskin, E. Gökaşan and H. Tur, Late Quaternary sedimentation and tectonics in the submarine Sarkoy Canyon, western Marmara Sea (Turkey). The Geodynamics of the Aegean and Anatolia, T. Taymaz, Y. Yilmaz and Y. Dilek, London, Special Publications, 291, 231-57, 2007.

Fleitmann, D., H. Cheng, S. Badertscher, R. L. Edwards, M. Mudelsee, O. M. Göktürk, A. Fankhauser, R. Pickering, C. C. Raible, A. Matter, J. Kramers and O. Tüysüz: Timing and climatic impact of Greenland interstadials recorded in stalagmites from northern Turkey, Geophysical Research Letters, 36, 10.1029/2009GL040050, 2009.

Genov, I.: Seismostratigraphy and the last Black Sea level changes, Geologie, 68, 1419-24, 2015.

Gokasan, E., M. Ergin, M. Ozyalvac, I. H. Sur, H. Tur, T. Gorum, T. Ustaomer, F. G. Batuk, H. Alp, H. Birkan, A. Turker, E. Gezgin and M. Ozturan: Factors controlling the morphological evolution of the Canakkale Strait (Dardanelles, Turkey), Geo-Mar Letters, 28, 107-29, 2008.

Gökaşan, E., T. Hüseyin, M. Ergin, T. Görüm, F. G. Batuk, N. Sağci, T. Ustaömer, O. Emem and H. Alp: Late Quaternary evolution of the Çanakkale Strait region (Dardanelles, NW Turkey): implications of a major erosional event for the postglacial Mediterranean-Marmara Sea connection, Geo-Mar Letters, 30, 113-31, 10.1007/s00367-009-0166-2, 2010.

Grall, C., P. Henry, Y. Thomas, G. K. Westbrook, M. N. Çağatay, B. Marsset, H. Saritas, G. Çifçi and L. Géli: Slip rate estimation along the western segment of the Main Marmara Fault over the last 405-490 ka by correlating mass transport deposits, Tectonics, 32, pp. 1587-601, 2013.

Henderson, G. M., D. J. Martel, R. K. O'Nions and N. J. Shackleton: Evolution of seawater Sr-87/Sr-86 over the last 400-ka - the absence of glacial interglacial cycles, Earth and Planetary Science Letters, 128, 1994.

Hiscott, R. N., A. E. Aksu, D. Yasar, M. A. Kaminski, P. J. Mudie, V. Kostylev, J. C. MacDonald and A. R. Lord: Deltas south of the Bosporus record persistent Black Sea outflow to the Marmara Sea since 10 ka, Marine Geology, 190, 95-118, 2002.

Karakilcik, H., U. Can Unlugenc and M. Okyar: Late glacial-Holocene shelf evolution of the Sea of Marmara west of Istanbul, Journal of African Sciences, 100, 365-78, 10.1016/j.jafrearsci.2014.06.003, 2014.

Lambeck, K., Y. Yokoyama and T. Purcell: Into and out of the Last Glacial Maximum: sealevel change during Oxygen Isotope Stages 3 and 2, Quaternary Science Reviews, 21, 343-60, 2002b.

Lericolais, G., C. Bulois, H. Gillet and F. Guichard: High frequency sea level fluctuations recorded in the Black Sea since the LGM, Global Planet Change, 66, 65-75, 10.1016/j.gloplacha.2008.03.010, 2009.

Liu, Z. and K.-F. Huang: Clay mineral distribution in surface sediments of the northeastern South China Sea and surrounding fluvial discharge basins: Source and transport, Marine Geology, 277, 48-60, 2010.

Major, C., S. Goldstein, W. Ryan, G. Lericolais, A. M. Piotrowski and I. Hajdas: The coevolution of Black Sea level and composition through the last deglaciation and its paleoclimatic significance, Quatern. Sci. Rev., 25, 2031-47, doi:10.1016/j.quascirev.2006.01.032, 2006.

Mallison, D. and G. Brook: Optically stimulated luminescence age controls on late Pleistocene and Holocene coastal lithosomes, North Carolina, USA, Quaternary Research, 69, 97-109, 2008. 
McHugh, C. M. G., D. Gurung, L. Giosan, W. B. F. Ryan, Y. Mart, U. Sancar, L. Burckle and M. N. Çagatay: The last reconnection of the Marmara Sea (Turkey) to the World Ocean: A paleoceanographic and paleoclimatic perspective, Marine Geology, 255, 64-82, 10.1016/j.margeo.2008.07.005, 2008.

Members, E. C.: One-to-one coupling of glacial climate variability in Greenland and Antarctica, Nature, 444, 195, 2006.

Nowaczyk, N. R., H. W. Arz, U. Frank, J. Kind and B. Plessen: Dynamics of the Laschamp geomagnetic excursion from Black Sea sediments, Earth and Planetary Science Letters, 351-352, 54-69, 10.1016/j.eps1.2012.06.050, 2012.

Palmer, M. R. and J. M. Edmond: The strontium budget of the modern ocean, Earth and Planetary Science Letters, 92, 11-26, 1989.

Peltier, W. R. and R. G. Fairbanks: Global glacial ice volume and Last Glacial Maximum duration from an extended Barbados sea level record, Quaternary Science Reviews, 25, 3322-37, 10.1016/j.quscirev.2006.04.010, 2006.

Pico, T., J. R. Creveling and J. X. Mitrovica: Sea-level records from the U.S. mid-Atlantic constrain Laurentide Ice Sheet extent during Marine Isotope Stage 3, Nature Communications, 10.1038/ncomms15612, 2017.

Pico, T., J. X. Mitrovica, K. L. Ferrier and J. Braun: Global ice volume during MIS 3 inferred from a sea-level analysis of sedimentary core reciords in the Yellow River Delta, Quaternary Science Reviews, 152, 72-79, 2016.

Rochon, A., P. J. Mudie, A. E. Aksu and H. Gillespie: Ptericysta Gen. Nov.: A new dinoflagellate cyst from pleistocene glacial-stage sediments of the Black and Marmara Seas, Palynology, 26, 95-105, 2002.

Shakun, J. D., D. W. Lea, L. E. Lisiecki and M. E. Raymo: An 800-kyr record of global surface ocean $\delta 180$ and implications for ice volume-temperature coupling, Earth and Planetary Science Letters, 426, 58-68, 2015.

Siddall, M., E. J. Rohling, W. G. Thompson and C. Waelbroeck: Marine isotope stage 3 sea level fluctuations: data synthesis and new outlook, Review of Geophysics, 46, 10.1029/2007RG000226, 2008.

Smith, A. D., T. Taymaz, F. Oktay, H. Yuce, B. Alpar, H. Basaran, J. A. Jackson, S. Kara and M. Simsek: High resolution seismic reflection profiling in the sea of Marmara (northwest Turkey): Late Quaternary sedimentation and sea-level changes, Bulletin of Geologicak Society of America, 107, 923-36, 10.1130/0016-7606(1995), 1995.

Soulet, G., G. Delaygue, C. Vallet-Coulomb, M. E. Böttcher, C. Sonzogni, G. Lericolais and E. Bard: Glacial hydrologic conditions in the Black Sea reconstructed using geochemical pore water profiles, Earth and Planetary Science Letters, 296, 57-66, 10.1016/j.epsl.2010.04.045, 2010.

Van Daele, M., A. van Welden, J. Moernaut, C. Beck, F. Audermard, J. Sanchez, F. Jouanne, E. Carrillo, G. Malavé, A. Lemus and M. De Batist: Reconstruction of LateQuaternary sea- and lake-level changes in a tectonically active marginal basin using seismic statigraphy: The Gulf of Cariaco, NE Venezuela, Marine Geology, 279, 37$51,2011$.

Vardar, D., K. Öztürk, C. Yaltirak, B. Alpar and H. Tur: Late Pleistocene-Holocene evolution of the southern Marmara shelf and sub-basins: middle strand of the North Anatolian fault, southern Marmara Sea, Turkey, Marine Geophysical Research, 35, 69-85, 2014.

Vidal, L., G. Ménot, C. Joly, H. Bruneton, F. Rostek, M. N. Çağatay, C. Major and E. Bard: Hydrology in the Sea of Marmara during the last $23 \mathrm{ka}$ : Implications for timing of Black Sea connections and sapropel deposition, Paleoceanography, 25, 10.1029/2009PA001735, 2010. 
Clim. Past Discuss., https://doi.org/10.5194/cp-2019-30

Manuscript under review for journal Clim. Past

Discussion started: 20 March 2019

(c) Author(s) 2019. CC BY 4.0 License.

15

523

524

525

526

527

528

529

530

531

532

533

534

535

536

537

538

539

540

541

542

543

544

545

546

547

$548 \quad$ Figures

549

550
Yaltirak, C., M. Sakinc, A. E. Aksu, R. N. Hiscott, B. Galleb and U. B. Ulgen: Late Pleistocene uplift history along the southwestern Marmara Sea determined from raised coastal deposits and global sea-level variations, Marine Geology, 192, 283-305, 10.1016/S0025-3227(02)00351-1, 2002.

Yanchilina, A. G. (2016). Excess freshwater outflow from the Black Sea-Lake during glacial and deglacial periods and delayed entry of marine water in the early Holocene require evolving sills, Columbia University.

Yanchilina, A. G., W. B. F. Ryan, J. F. McManus, P. Dimitrov, D. Dimitrov, K. Slavova and M. Filipova-Marinova: Compilation of geophysical, geochronological, and geochemical evidence indicates a rapid Mediterranean-derived submergence of the Black Sea's shelf and subsequent substantial salinification in the early Holocene, Marine Geology, 383, 14-34, 10.1016/j.margo.2016.11.001, 2017.

Yokoyama, Y., P. De Deckker, K. Lambeck, P. Johnston and K. Fifield: Sea-level at the Last Glacial Maximum: evidence from northwestern Australia to constrain ice volumes for oxygen isotope stage 2, Paleoceanography, Palaeoclimatology, Palaeoecology, 165, 281-97, 10.1016/S0031-0182(00)00164-4, 2001.

\section{Acknowledgments}

The authors would like to acknowledge the crew of the Akademik 2009 and 2011 expeditions, Louise Bolge and Leo Pena for assistance with the geochemical analyses, Giovanni Aloisi, Helge Arz, Namik Çağatay, Samuel Goldberg for generating GIA corrections and helpful discussion, Candace Major for the ${ }^{87} \mathrm{Sr} /{ }^{86} \mathrm{Sr}$ records from the Sea of Marmara, Guillaume Soulet, and Bill Thompson for sharing datasets employed to reach our conclusions.

Figure 1: 
Clim. Past Discuss., https://doi.org/10.5194/cp-2019-30

Manuscript under review for journal Clim. Past

Discussion started: 20 March 2019

(c) Author(s) 2019. CC BY 4.0 License.

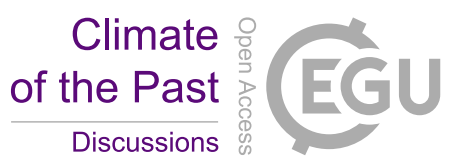

(c) (i)
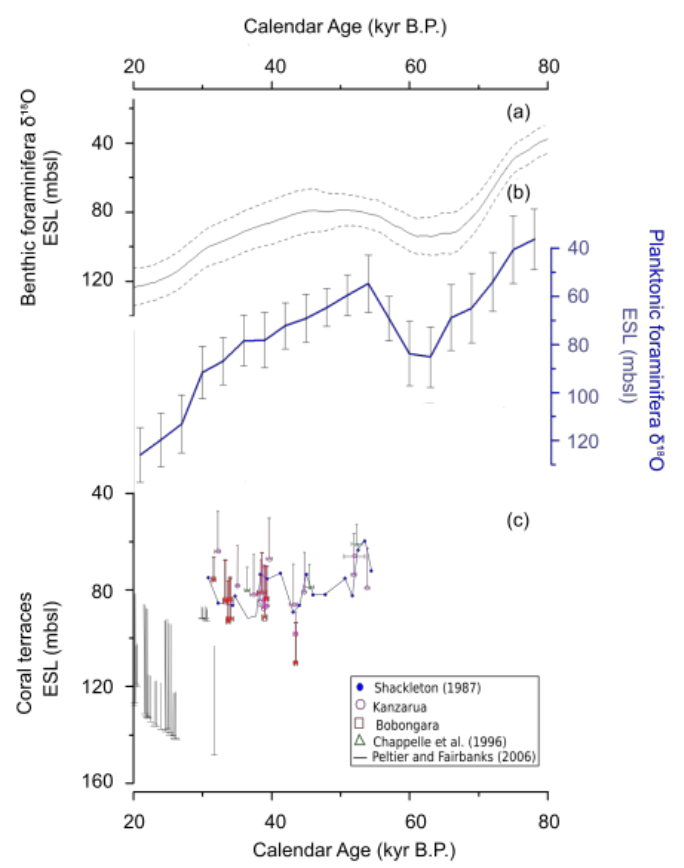

Figure 1. Prior sea-level reconstructions for MIS 3. (a) ESL reconstruction using inverse climate ice-sheet modelling from $\delta^{18} \mathrm{O}$ LR04 record (Bintanja et al. 2005). (b) ESL derived from extraction of ice volume from planktonic $\delta^{18} \mathrm{O}$ (Shakun et al. 2015). (c) ESL reconstruction corrected for regional uplift and GIA (Yokoyama et al. 2001, Peltier et al. 2006).

560

561

562

563 Figure 2: 
Clim. Past Discuss., https://doi.org/10.5194/cp-2019-30

Climate

Manuscript under review for journal Clim. Past

Discussion started: 20 March 2019

(c) Author(s) 2019. CC BY 4.0 License.
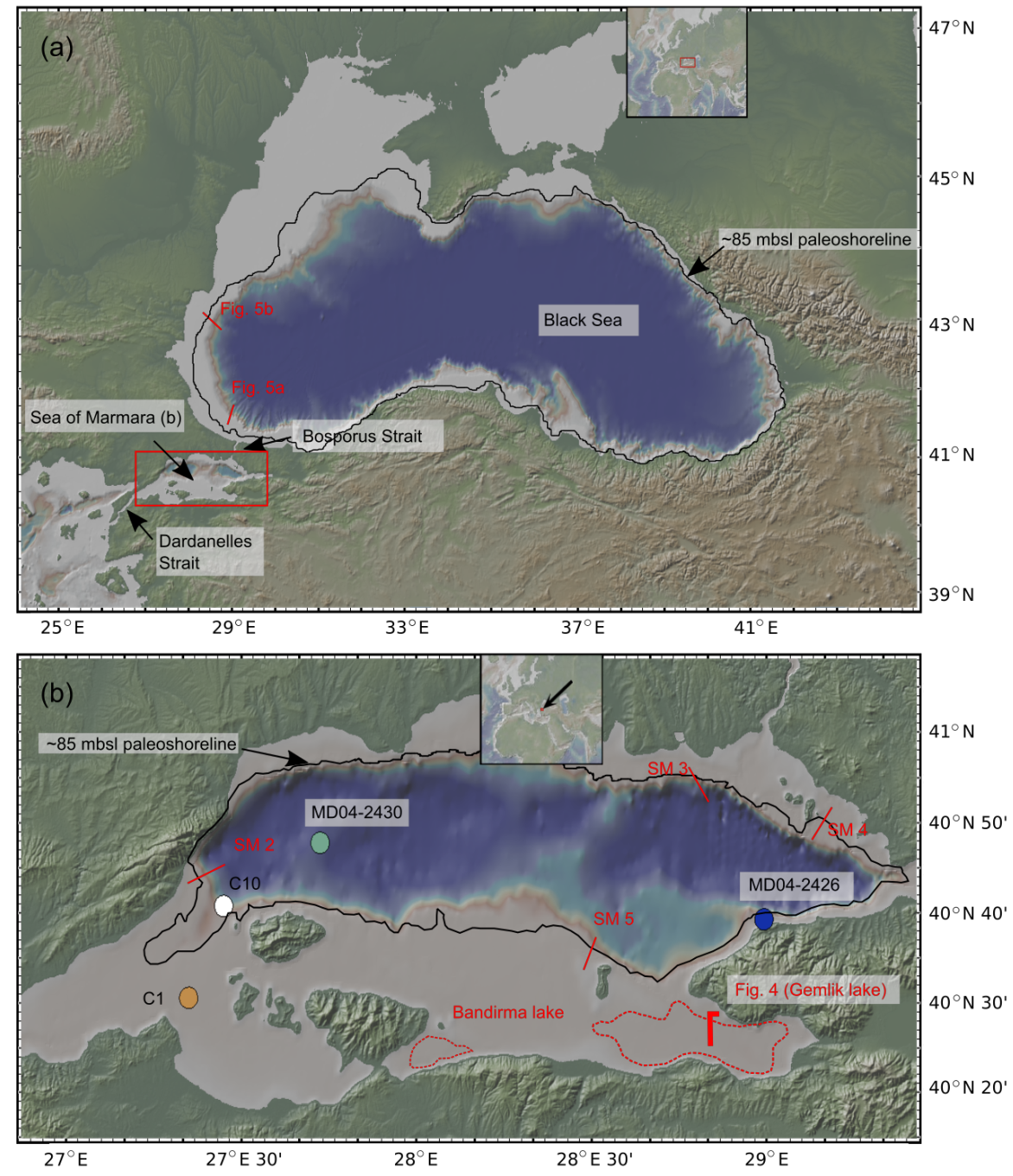

Figure 2: Map of the Black Sea (a) and Sea of Marmara (b). Important geographical features are indicated. (a) Location of the Black Sea, Sea of Marmara relative to the Black Seam Bosporus Strait and the Dardanelles Strait. Also are indicated the seismic profiles provided in figure $5 \mathrm{a}$ and $5 \mathrm{~b}$. The location of the $\sim 85 \mathrm{mbsl}$ paleoshoreline is pointed out. (b) Indicated are the locations of the Gemlik and Bandirma perched lakes in addition to the location of the seismic profile for Gemlik lake presented in Fig. 4. Also are indicated the locations of the cores MD04-2426, MD04-2430, C1, and C10. The locations of the seismic profiles provided in the supplementary materials are also indicated as SM 2, SM 3, SM 4, and SM5. 
Clim. Past Discuss., https://doi.org/10.5194/cp-2019-30

Climate

Manuscript under review for journal Clim. Past

Discussion started: 20 March 2019

(c) Author(s) 2019. CC BY 4.0 License.

Figure 3. Changes in geochemical proxies during MIS 3. (a) ${ }^{87} \mathrm{Sr} /{ }^{86} \mathrm{Sr}$ from the Black and

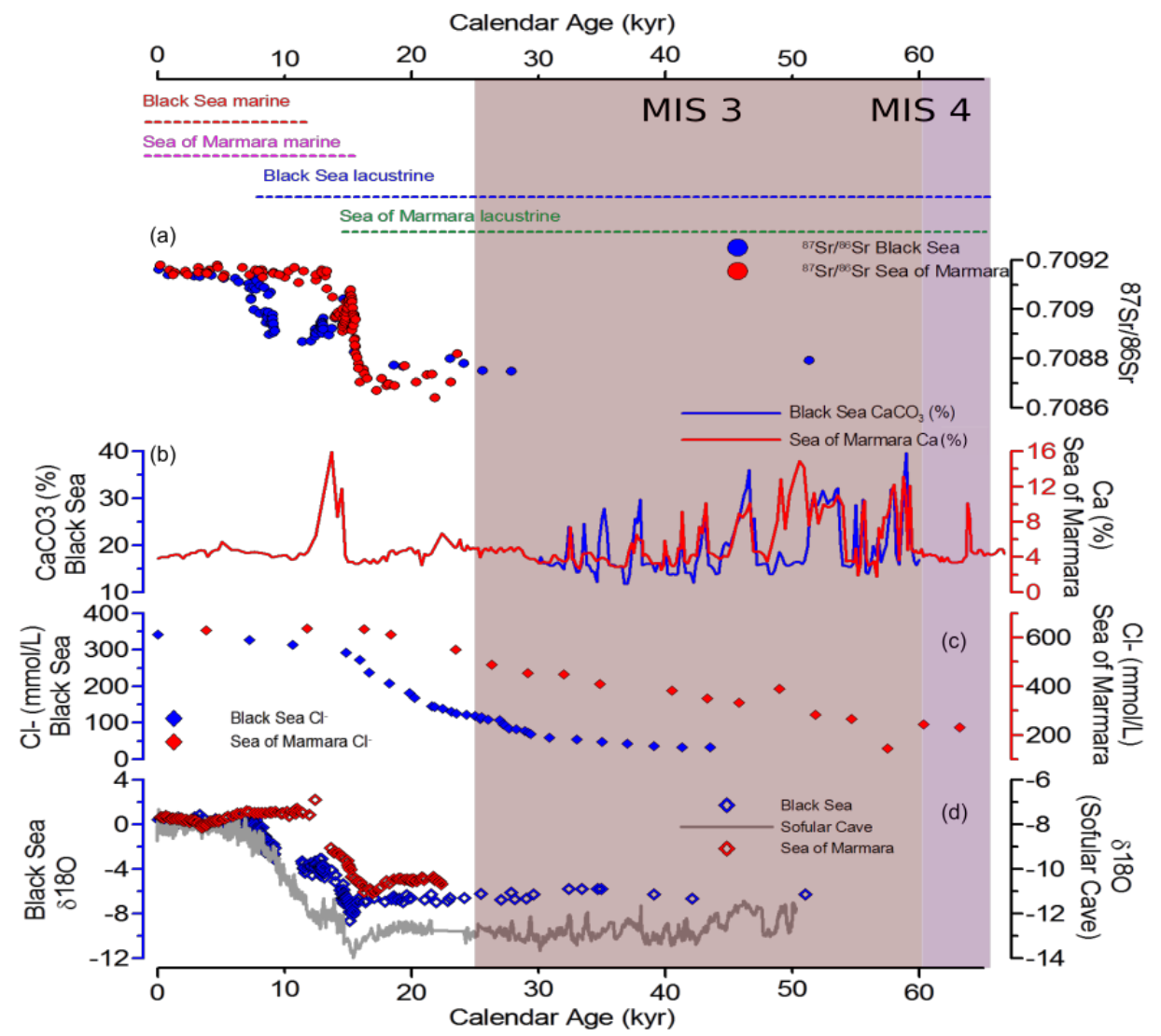
Marmara Sea-Lakes (C.O. Major, National Science Foundation) ${ }^{87} \mathrm{Sr} /{ }^{86} \mathrm{Sr}$ from the Black Sea is taken from the work of Major et al. (2006), Yanchilina et al. (2017), Yanchilina et al. (2019); the ${ }^{87} \mathrm{Sr} /{ }^{86} \mathrm{Sr}$ from the Marmara Sea is what is what measured in the present manuscript. (b) $\mathrm{CaCO}_{3}$ from the Black Sea-Lake (Nowaczyk et al. 2012) and Ca from the Marmara Sea-Lake (Çağatay et al. 2015). (c) Black Sea and Sea of Marmara porewater chlorinity, respectively (Soulet et al. 2010, Aloisi et al. 2015). (d) $\delta^{18} \mathrm{O}$ from the Black Sea (blue), the Sea of Marmara (red) (Vidal et al. 2010) and Sofular Cave (grey) $\delta^{18} \mathrm{O}$ (Badertscher et al. 2011). 
Clim. Past Discuss., https://doi.org/10.5194/cp-2019-30

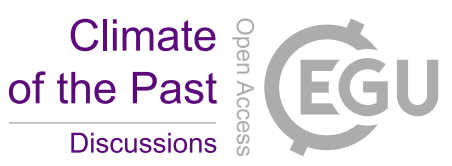

Discussion started: 20 March 2019

(c) Author(s) 2019. CC BY 4.0 License.

(c) $\underset{\mathrm{Br}}{(i)}$

600

601

602

603

604

605

606

607

608

609

610

611

612

613

614

615

616

617

618

619

620

621

622

623

624

625

626

627

628

629

630

631

632

633

634

635

Figure 4:

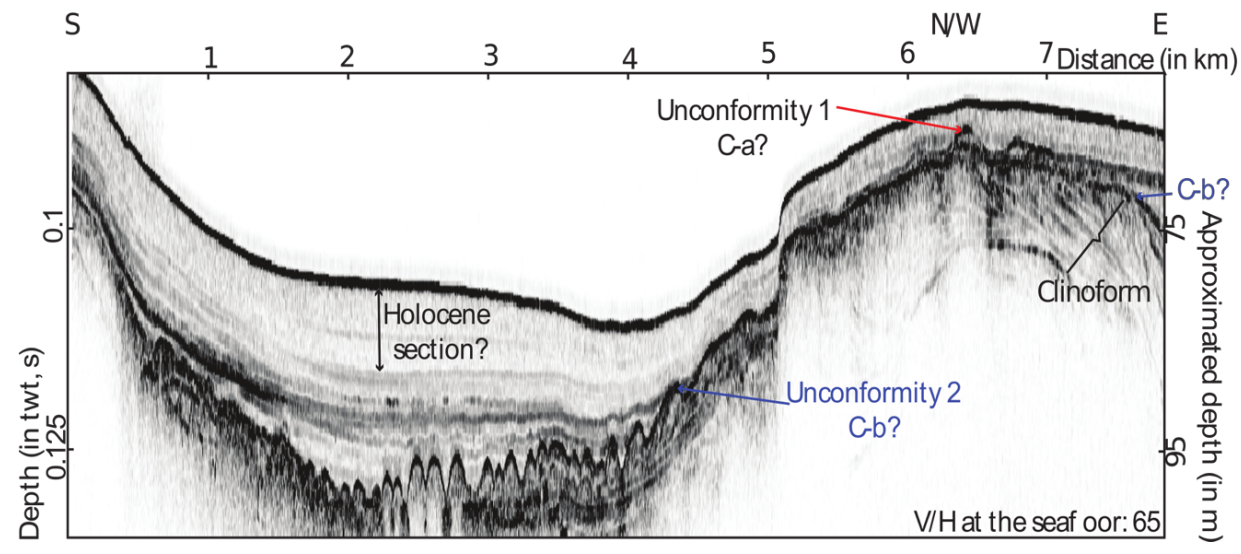

Figure 4. Chirp sub-bottom profile across the Gemlik Bay. 2 unconformities on the shore of the Bay, only one in the lake. The shallowest one has been estimated to be associated with the Last Marine-Lacustrine transition and the deepest. 
Clim. Past Discuss., https://doi.org/10.5194/cp-2019-30

Climate

Manuscript under review for journal Clim. Past

Discussion started: 20 March 2019

(c) Author(s) 2019. CC BY 4.0 License.

Discussions

(c) (i)

Figure 5:

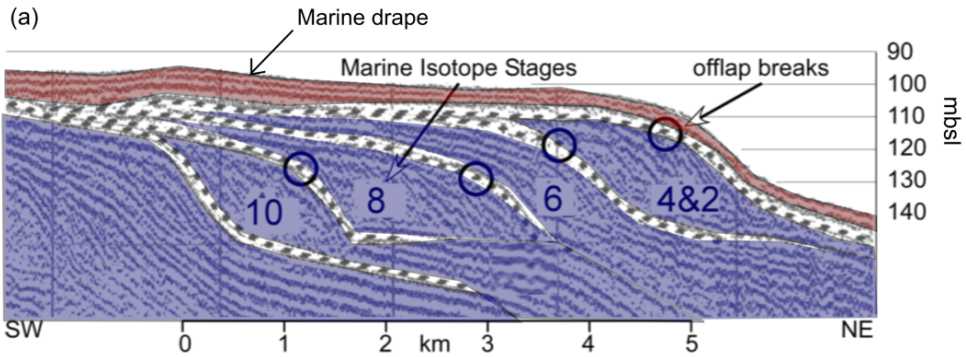

(b)
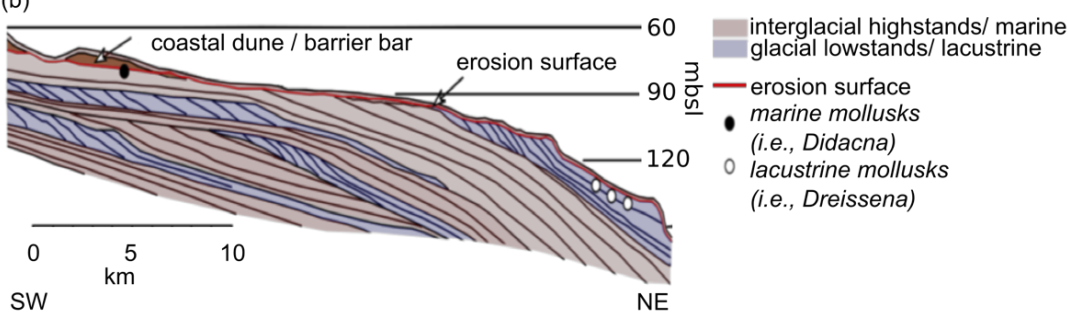

Figure 5. Reflection profiles on the SW shelf of the Black Sea. (a) Succession of superimposed prograding clinoforms adopted from a previously published illustration (Fig. 11c) (Aksu et al. 2002) with offlap breaks indicating present and past locations of lowstand deltas at the shelf edge. Numbers are inferred MIS stages when the Black Sea was a freshwater lake. (b) A similar succession with thinner glacial-age lowstand clinoforms (blue) and thicker interglacial highstand deposits adopted from an earlier published XIX profile retrieved from $\mathrm{R} / \mathrm{V}$

648 Hydrograph in 1998 (Genov 2015). White circles indicate sampling of lacustrine mollusks of 649 MIS 2 and 3 age; black circles indicate sampling of marine mollusks presumable of MIS 5 age 650 (Dimitrov 2010). Coastal dunes place the MIS 3 and 2 shorelines at elevations between 80 and $65190 \mathrm{mbsl}$. 